\title{
FAKTOR-FAKTOR YANG MEMPENGARUHI KEPUTUSAN PEMBELIAN PRODUK PADA DISTRO LEGEND STORE DI KECAMATAN NUSA PENIDA
}

\author{
I Komang Sukarnaya ${ }^{1}$, Lulup Endah Tripalupi ${ }^{2}$, I Nyoman Sujana ${ }^{3}$ \\ Program Studi Pendidikan Ekonomi \\ Universitas Pendidikan Ganesha \\ Singaraja, Indonesia
}

\begin{abstract}
email: komangkarnaya@gmail.com¹, endah.tripalupi@undiksha.ac.id², nyoman.sujana@undiksha.ac.id ${ }^{3}$
\end{abstract}

\begin{abstract}
Abstrak
Penelitian ini bertujuan untuk mengetahui fakor-faktor dan faktor yang paling dominan mempengaruhi keputusan pembelian produk pada Distro Legend Store di Kecamatan Nusa Penida. Jenis penelitian ini adalah penelitian eksploratif dengan menggunakan rancangan penelitian faktorial. Populasi dalam penelitian ini adalah konsumen yang berbelanja di Distro Legend Store yang berjumlah 100 orang, yang diambil dengan menggunakan teknik incidental sampling. Data dikumpulkan menggunakan kuesioner. Data dianalisis menggunakan analisis faktor dengan program SPSS 16.0 for Windows. Hasil penelitian menunjukkan bahwa terdapat empat faktor yang mempengaruhi keputusan pembelian produk pada Distro Legend Store di Kecamatan Nusa Penida, yaitu faktor pribadi dengan nilai variance sebesar $61,901 \%$, faktor sosial dengan nilai variance sebesar $18,388 \%$, faktor psikologis dengan nilai variance sebesar $15,023 \%$, dan faktor budaya dengan nilai variance sebesar $4,688 \%$. Faktor pribadi menjadi faktor yang paling dominan, karena memiliki nilai varimax rotation sebesar $61,901 \%$, artinya total nilai varimax rotation dari faktor pribadi mampu menjelaskan keputusan pembelian produk pada Distro Legend Store sebesar $61,901 \%$.
\end{abstract}

Kata Kunci: Keputusan Pembelian, Faktor Budaya, Faktor Sosial, Faktor Pribadi, Faktor Psikologis

\begin{abstract}
The aim of this research is to know factors and the most dominant factor affecting a decision of buying products at Legend Store Distro in Nusa Penida Subdistrict. This study was an exploratory research with factorial research design. The population of this research was consumers who are buying at Legend Store Distro with total number 100 people, taken by using incidental sampling technique. The data were collected by using questioneer. The data were analized by using factors analysis with SPSS 16.0 program for Windows. The result of the research showed that there were four factors affecting the decisions of buying product at Legend Store Distro in Nusa Penida Subdistrict, were personal factor with variance value $61,901 \%$, social factor with variance value $18,388 \%$, psycology factor with variance value 15,023 , and culture factor with variance value 4,688. Personal factor was the most dominant factor, because having varimax rotation value $61,901 \%$, means the total value of varimax rotation of personal factor is able to explain the decision of buying product at Legend Store Distro as much as $61,901 \%$.
\end{abstract}

Keywords: Decisions of Buying, Culture Factor, Social Factor, Personal Factor, Psychology Factor 


\section{PENDAHULUAN}

Banyaknya perusahaan yang bergerak dalam industry fashion saat ini akan menimbulkan persaingan yang semakin ketat. Persaingan yang semakin ketat membuat konsumen dihadapkan pada banyak pilihan. Berkenaan dengan hal tersebut, pelaku bisnis harus berusaha semaksimal mungkin untuk membuat konsumen tertarik terhadap produk yang dihasilkan sehingga konsumen mengambil keputusan untuk membeli produk yang dihasilkan oleh suatu perusahaan. Menurut Swasta dan Handoko (2000) keputusan pembelian adalah sebuah pendekatan penyelesaian masalah pada kegiatan manusia untuk membeli suatu barang atau jasa dalam memenuhi keinginan dan kebutuhannya yang terdiri dari pengenalan kebutuhan dan keinginan, pencarian informasi, evaluasi terhadap alternatif pembelian, keputusan pembelian, dan tingkah laku saat pembelian. Menurut Schifman dan Kanuk (2004) perilaku konsumen adalah proses yang dilalui oleh seseorang dalam mencari, membeli, menggunakan, mengevaluasi, dan bertindak pasca konsumsi produk, jasa, maupun ide yang diharapkan dapat memenuhi kebutuhannya. Hubungannya dengan keputusan pembelian suatu produk atau jasa, pemahaman mengenai perilaku konsumen meliputi jawaban atas pertanyaan seperti apa (what) yang dibeli, di mana membeli (where), bagaimana kebiasaan (how often) membeli dan dalam keadaan apa (under what condition) barang-barang dan jasa-jasa dibeli.

Pemasar ingin memahami bagaimana respon di dalam karakteristik pembeli dan proses keputusan pembeli. Dimana karakteristik pembeli mempengaruhi bagaimana pembeli menerima dan bereaksi terhadap rangsangan itu. Sedangkan proses keputusan pembeli itu sendiri mempengaruhi perilaku pembeli. Menurut Kotler dan Amstrong (2008:159) bahwa "karakteristik pembeli mempengaruhi perilaku pembeli dan kemudian mendiskusikan proses keputusan pembeli". Menurut Kotler dan Amstrong (2001:226) "keputusan pembelian adalah tahap dalam proses pengambilan keputusan pembelian di mana konsumen benar-benar membeli".
Pengambilan keputusan merupakan suatu kegiatan pribadi yang secara langsung terlibat dalam mendapatkan dan mempergunakan barang yang ditawarkan. Sejalan dengan Schifman dan Kanuk (2000:437) "keputusan pembelian adalah the selection of an option from two or alternative choice". Sedangkan menurut Munandar (2001) pengambilan keputusan membeli adalah proses pengenalan masalah (problem recognition), pencarian informasi, evaluasi (penilaian) dan seleksi dari alternatif produk, seleksi saluran distribusi dan pelaksanaan keputusan terhadap produk yang akan digunakan atau dibeli oleh konsumen. Berdasarkan pengertian di atas, maka dapat disimpulkan bahwa keputusan pembelian adalah proses pengenalan masalah (problem recognition), pencarian informasi, evaluasi (penilaian) dan seleksi dari alternatif produk yang dilakukan individu atau kelompok dalam memenuhi kebutuhan dan keinginannya.

Perilaku konsumen akan menentukan proses pengambilan keputusan dalam pembelian mereka. "Pada umumnya proses pembelian terhadap barang atau jasa meliputi pengenalan kebutuhan, pencarian informasi, evaluasi alternatif, keputusan pembelian, dan perilaku pasca pembelian" (Kotler dan Amstrong, 2001:222).

Proses keputusan pembelian melibatkan bermacam-macam faktor yang mempengaruhi pembeli. Menurut Kotler (2002) lima peran yang dimainkan orang dalam keputusan pembelian yaitu pencetus (initiator) adalah seseorang yang pertama kali mengusulkan gagasan untuk membeli suatu produk atau jasa, pemberi pengaruh (influencer) adalah seseorang yang pandangan atau sarannya mempengaruhi keputusan, pengambil keputusan (decider) adalah seseorang yang mengambil keputusan untuk setiap komponen keputusan pembelian, apakah membeli, tidak membeli, bagaimana membeli dan dimana akan membeli, pembeli (buyer) adalah orang yang melakukan pembelian yang sesungguhnya. Pengenalan kebutuhan pencarian informasi evaluasi berbagai alternatif keputusan pembelian perilaku pasca pembelian, dan pemakai (user) adalah seseorang yang 
mengkonsumsi atau menggunakan produk atau jasa yang bersangkutan.

Konsumen dalam membeli sesuatu, ada beberapa faktor yang perlu dipertimbangkan. Menurut Kotler (2005) terdapat empat faktor yang mempengaruhi perilaku keputusan pembelian konsumen yaitu budaya, sosial, pribadi, dan psikologis. Faktor budaya terdiri dari sub-budaya dan kelas sosial yang sangat penting bagi perilaku pembelian. Selain faktor budaya, perilaku konsumen juga dipengaruhi oleh faktor-faktor sosial seperti kelompok acuan, keluarga, serta peran dan status sosial. Keputusan pembelian juga dipengaruhi oleh faktor pribadi meliputi usia dan tahap siklus hidup, pekerjaan, keadaan ekonomi, gaya hidup, serta kepribadian pembeli. Pilihan pembelian seseorang juga dipengaruhi oleh faktor psikologi utama yaitu motivasi, persepsi, pembelajaran, serta keyakinan dan sikap.

Masyarakat saat ini sudah sangat menyadari akan kebutuhan fashion yang lebih dari sekedar berpakaian, tapi juga bergaya dan trendi. Pakaian merupakan ekspresi indentitas pribadi, maka masyarakat sadar atau tidak sadar bisa menilai kepribadian seorang dari apa yang dipakainya. Oleh karena itu kehadiran distro menjadi tuntutan perubahan gaya hidup masyarakat kota. Kondisi semacam ini mencerminkan suatu fenomena yang terjadi bahwa masyarakat menjadi semakin kritis dalam memilih tempat belanja. Sifat kritis tersebut dicirikan bahwa masyarakat menginginkan barang atau produk yang berkualitas, pelayanan, dan fasilitas yang memuaskan yang semuanya terdapat dalam satu tokoh yaitu distro. Produk distro saat ini berkembang sangat cepat mengikuti perkembangan zaman yang ada dan terkait dengan tren yang sedang berlaku, kreativitas dan gaya hidup. Penelitian ini berkaitan dengan penelitian yang dilakukan oleh Murdoyo (2014) yang menunjukkan bahwa faktor pribadi yang paling dominan mempengaruhi konsumen dalam pengambilan keputusan pembelian produk Sepatu Futsal Merk Adidas pada Pelanggan Lapangan Futsal Gor Surya di Boyolali.

Distro atau distribution store merupakan toko distribusi yang menjual berbagai produk ( $t$-shirt, kemeja, topi, hoodie, tas, dompet, celana, sepatu, dan lain-lain) yang berfungsi menerima titipan dari berbagai macam merek clothing company. Sedangkan clothing adalah produsen yang memproduksi sendiri semua produk dengan label sendiri pula. Sebuah clothing bisa memiliki toko sendiri atau hanya sekedar menitipkan produk mereka di distro. Keuntungan distro adalah keesklusifan produknya, selain desain yang menampilkan simbol-simbol kebebasan dan selalu up to date dan fresh sehingga benarbenar lebih bisa merebut hati anak muda. Jumlah yang terbatas dengan desain yang berkarakter menjadi ciri tersendiri dari produk yang didistribusikan.

Salah satu distro di Nusa Penida adalah Legend Store. Distro Legend Store adalah salah satu konsep distro yang berdiri sejak tahun 2013 . Usaha bisnis yang berada pusat kota di Jl. Nusa Indah Mentigi Nusa Penida ini terlihat berbeda bila dibandingkan dengan distro lain yang ada di Nusa Penida. Mulai desain interiornya hingga konsep distro tersebut berbeda dengan distro yang lain. Dengan menggunakan kosep yang berbeda bila dibandingkan dengan distro lain yang ada di Nusa Penida, perbedaan ini mengakibatkan Legend Store terus mencoba menyediakan produk-produk yang berkualitas dan pelayanan yang maksimal. Produk-produk yang ada di Legend Store merupakan produk bermerek yang sudah memiliki komunitas dan penggemarnya masing-masing seperti "Deaf Authentic" "Violence" "Deathhord" "Mosley" "Scremotion" "Lick" "Voor Durend" dan Legend itu sendiri. Jadi selain menjual produk orang lain, Legend Store juga memiliki produk sendiri yang diberi label Legend.

Legend Store dalam memasarkan produknya mencakup seluruh wilayah di Nusa Penida. Dalam mengembangkan usahanya pemilik melihat dari dua sektor yaitu eksternal yang berupa pesaing, pendatang baru, dan supplier. Sedangkan dari sektor internal dilihat dari kekuatan dan kelemahan manajemen dalam mengembangkan usaha dan produk usahanya. Berdasarkan penelitian pendahuluan yang dilaksanakan dari bulan 
Oktober 2017-Februari 2018 Legend Store cenderung mengalami penurunan omset penjualan. Omset penjualan pada bulan Oktober 2017 sebesar Rp. 97.340.000,-Sedangkan pada bulan November 2017 sampai bulan Februari 2018 mengalami penurunan mencapai Rp. 38.657.000,-.

Melalui penelitian ini berupaya untuk mengungkap "Faktor-Faktor yang Mempengaruhi Keputusan Pembelian Produk pada Distro Legend Store di Kecamatan Nusa Penida".

\section{METODE}

Jenis penelitian ini adalah penelitian eksploratif yang menganalisis faktor-faktor yang mempengaruhi keputusan pembelian dan untuk mengetahui faktor mana yang paling dominan mempengaruhi keputusan pembelian pada Distro Legend Store. Oleh karena itu, dalam pelaksanaan penelitian ini akan menggunakan rancangan penelitian faktorial di mana data dalam penelitian ini dianalisis dengan menggunakan analisis faktor. Terdapat empat faktor yang mempengaruhi keputusan pembelian pada Distro Legend Store di Kecamatan Nusa Penida yaitu faktor budaya, faktor sosial, faktor pribadi, dan faktor psikologis. Hasil penelitian ini diharapkan mampu memberikan gambaran dan informasi bahwa keputusan pembelian adalah penting untuk menanggulangi kerugian dan meningkatkan keuntungan perusahaan.

Lokasi penelitian merupakan tempat dimana peneliti akan melakukan penelitian. Penelitian ini dilakukan di Kecamatan Nusa Penida. Populasi penelitian yang digunakan adalah konsumen yang berbelanja di Distro Legend Store yang jumlahnya tidak terhingga. Menurut Sujarweni (2015:80) "populasi adalah keseluruhan jumlah yang terdiri atas objek atau subjek yang mempunyai keraketeristik dan kualitas tertentu yang ditetapkan oleh peneliti untuk diteliti dan kemudian ditarik kesimpulannya".

Teknik yang digunakan dalam mengambil sampel adalah teknik incidental sampling. Menurut Sujarweni (2015:87-88) "incidental sampling adalah teknik penentuan sampel berdasarkan kebetulan, yaitu siapa saja yang secara kebetulan/insidental bertemu dengan peneliti, maka dapat digunakan sebagai sampel, bila dipandang orang yang kebetulan ditemui itu cocok sebagai sumber data". Dalam penelitian ini jumlah sampel yang diperoleh minimal sebanyak 100 responden.

Jenis data dalam penelitian ini adalah kuantitatif. Menurut Sugiyono (2013:14) "data kuantitatif adalah data yang berbentuk angka dan dapat dinyatakan dalam satuan hitung". Data kuantitatif dalam penelitian ini berupa skor dari hasil kuesioner mengenai faktor-faktor yang mempengaruhi keputusan pembelian pada Distro Legend Store.

Data kuantitatif yang dimaksud dalam penelitian ini adalah hasil jawaban responden terhadap kuesioner. Selanjutnya data yang diperoleh dalam penelitian ini akan dianalisis menggunakan analisis fakor sehingga dari analisis tersebut dapat ditarik kesimpulan.

Sumber data yang digunakan dalam penelitian ini adalah data primer. Data primer yaitu data yang diperoleh secara langsung dari responden terkait faktorfaktor yang mempengaruhi keputusan pembelian. Peneliti memperoleh data atau informasi langsung dengan menggunakan instrumen-instrumen yang telah ditetapkan.

Metode pengumpulan data yang digunakan dalam penelitian ini adalah kuesioner. Dimana kuesioner digunakan untuk mengumpulkan data dengan menggunakan daftar pernyataan yang ditujukan kepada konsumen mengenai budaya, sosial, pribadi, dan psikologis. Instrumen penelitian ini adalah kuisioner yang disebarkan kepada responden sebagai sampel yang mampu mewakili keseluruhan populasi, yaitu konsumen Distro Legend Store di Kecamatan Nusa Penida. Kuisioner yang dirancang dengan menggunakan Skala Likert. Menurut Sugiyono (2007) Skala Likert digunakan untuk mengukur sikap, pendapatan dan persepsi seseorang atau kelompok orang tentang fenomena sosial. Dalam penelitian ini variabel yang akan diuji, pada setiap jawaban akan diberi skor atau bobot. Dari jawaban responden akan diberikan skor menggunakan skala likert dengan rentang 1-5, jika jawaban sangat sangat setuju diberi skor 5 , jika jawaban 
setuju diberi skor 4, jika jawaban cukup setuju diberi skor 3, jika jawaban kurang setuju diberi skor 2, sedangkan jika jawaban sangat tidak setuju diberi skor 1 .

Terlebih dahulu instrumen penelitian ini diuji dengan dua jenis pengujian. Adapun pengujian yang dilakukan adalah pengujian validitas dan pengujian reliabilitas. Uji validitas Menurut Sugiyono (2008:172) "validitas berasal dari kata validity, yang berati instrumen itu dapat digunakan untuk mengukur apa yang seharusnya diukur". Uji validitas digunakan untuk mengukur sejauh mana ketepatan dan kecermatan suatu alat ukur dalam melakukan fungsinya.

Suatu instrumen dikatakan valid apabila mampu mengukur apa yang diinginkan serta dapat mengungkap dalam variabel yang diteliti secara tetap. Instrumen yang digunakan dalam penelitian terlebih dahulu diuji cobakan pada 30 konsumen yang berbelaja di Distro Legend Store. Cara yang digunakan adalah dengan analisis item, dimana setiap nilai yang ada pada setiap butir pertanyaan/pernyataan dikorelasikan dengan nilai total seluruh butir pertanyaan untuk suatu variabel dengan menggunakan rumus korelasi product moment pearson dengan menggunakan program SPSS 16.0 for Windows. Sedangkan, "Uji Reliabilitas adalah derajat ketepatan, ketelitian atau keakuratan yang ditunjukan oleh instrumen pengukuran" (Umar, 2003:207). Uji reliabilitas atau kehandalan dalam suatu instrument penelitian (kuisioner) ini perlu dilakukan pengujian awal suatu analisis sebelum dilakukan pengujian selanjutnya. Tujuannya adalah untuk menunjukkan konsistensi dari jawaban-jawaban responden terhadap kuisioner yang diajukan dalam kuisioner tidak dipahami atau dimengerti oleh responden sehingga bila diajukan pada waktu yang berbeda, jawabannya pun akan berbeda. Dalam penelitian ini untuk menguji reliabilitas instrumen dilakukan dengan teknik One Shot. Pada teknik ini, pengukuran dilakukan dengan metode Cronbach Alpha dengan menggunakan program SPSS 16.0 for Windows.

Sesuai dengan perumusan masalah, tujuan penelitian, dan jenis data yang digunakan dalam penelitian ini adalah analisis faktor. Adapun tahapan dalam analisis faktor yaitu Membuat matrik, semua data akan diolah untuk menghasilkan matrik korelasi. Dengan adanya matrik korelasi dapat diidentifikasi variabel-variabel tertentu yang tidak mempunyai korelasi dengan variabel lain, sehingga dapat dikeluarkan dari analisis. Untuk menguji ketepatan model analisis faktor, maka dapat digunakan Barlett's Test of Sphericity yang digunakan untuk menguji bahwa variabelvariabel dalam sampel berkorelasi. Hasil Barlett's Test of Sphericity menunjukan apakah hubungan antara variabel-variabel signifikan atau tidak. Statistik lain yang berguna adalah pengukuran adalah kelayakan sampel Kaiser Mayer Olkin (KMO). Analisis faktor dianggap layak jika besaran KMO nilainya minimal 0,50. Besaran lain yang dilihat adalah nilai Measure of Sampling Adequacy (MSA). Besaran ini digunakan untuk mengukur derajat korelasi antar variabel dengan kriteria $M S A \geq 0,50$.

Menentukan jumlah faktor, variabel disusun kembali berdasarkan pada korelasi hasil langkah pada butir dan untuk menentukan jumlah faktor yang diperlukan untuk mewakili data. Untuk itu ditentukan beberapa faktor yang dapat diterima dan dapat dilakukan berdasarkan besarnya eigenvalue setiap faktor yang muncul. Semakain besar eigenvalue setiap faktor, semakin representative faktor tersebut untuk mewakili sekelompok variabel. Faktor-faktor inti dipilih adalah faktor yang mempunyai eigenvalue $\geq 1$ pada total variance explained.

Rotasi faktor, hasil penyederhanaan faktor dalam matrik faktor memperlihatkan hubungan antara faktor dengan variabel individu, tetapi dalam faktor-faktor tersebut terdapat banyak variabel yang berkorelasi sehingga sulit diinterprestasikan. Dengan menggunakan rotasi faktor matrik, matrik faktor terubah ke dalam matrik yang lebih sederhana sehingga mudah untuk diinterprestasikan. Dalam prilaku ini digunakan rotasi varimax.

Interprestasi faktor, dilakukan dengan mengelompokkan variabel yang mempunyai faktor loading tinggi ke dalam faktor tersebut. Untuk menginterprestasikan hasil penelitian ini, faktor loading minimal 
0,5. Variabel yang mempunyai faktor loading kurang dari 0,5 dikeluarkan dari model.

Menentukan ketepatan model, tahap terakhir dari analisis faktor adalah mengetahui apakah model mampu menjelaskan dengan baik. Fenomena yang ada perlu diuji dengan teknik Principal Component Analysis (PCA) yaitu dengan melihat jumlah residual antara korelasi yang diamati dengan korelasi yang direproduksi. Dalam penelitian menggunakan alat bantuan hitung berupa program SPSS 16.0 for Windows.

Data yang didapat dari kuesioner masih berupa data oridinal, sedangkan analisis data yang dipakai untuk membuktikan kebenaran pengujian analisis faktor mengisyaratkan minimal data interval. Oleh karena itu, data oridinal tersebut perlu ditingkatkan sakala pengukurannya menjadi skala melalui "Method of Succestive Interval" (Riduwan, 2008) dengan langkah sebagai berikut. Ambil data dari kuesioner, untuk setiap pertanyaan hitung proporsi jawaban untuk setiap kategori jawaban dan hitung proporsi kumulatifnya, menghitung nilai $Z$ (tabel distribusi normal) untuk setiap proporsi kumulatif (untuk data $\mathrm{n}>30$ dianggap mendekati luas daerah di bawah kurve normal), menghitung nilai densitas untuk setiap proporsi kumulatif dengan memasukkan nilai $Z$ pada rumus distribusi normal. menentukan nilai transformasi (nilai untuk skala interval) dengan menggunakan rumus nilai transformasi $=$ Nilai Skala +1 Nilai Skala Minimal | + 1 .

\section{HASIL DAN PEMBAHASAN Hasil}

Analisis faktor yang digunakan untuk menganalisis hipotesis penelitian dengan memasukkan semua total nilai dari masingmasing dimensi. Skor dari masing-masing dimensi terlebih dahulu di ditransformasi kedalam data interval kemudian dilakukan penentuan matrik korelasi, penentuan jumlah faktor, rotasi faktor, interprestasi faktor, dan ketepatan model.

Selanjutnya dalam analisis faktor menguji matriks korelasi menggunakan Barlett's Test of Sphericity dengan koefisien Keiser-Meyer-Olkin (KMO) > 0,5 dengan signifikan $<0,05$, menentukan banyaknya faktor dengan memilih faktor atau komponen utama yang memiliki parameter akar karakteristik terkecil (eigenvalue) $>1$, dan menentukan faktor yang paling mendominasi menggunakan parameter koefisien varimax mendekati +1 dan -1 . Langkah pertama yang dilakukan yaitu dengan menganalisis jawaban responden terhadap angket yang telah dibagikan. Hasil analisis faktor melalui SPSS 16.0 for Windows menunjukkan persentase dari masing-masing faktor dapat dilihat pada tabel

\begin{tabular}{|c|c|c|}
\hline \multicolumn{3}{|c|}{ Kaiser-Meyer-Olkin Measure of Sampling Adequacy. } \\
\hline \multirow{3}{*}{$\begin{array}{l}\text { Bartlett's Test of } \\
\text { Sphericity }\end{array}$} & Approx. Chi-Square & 153.355 \\
\hline & Df & 6 \\
\hline & Siq. & .000 \\
\hline
\end{tabular}

Berdasarkan tabel 1 , hasil pengujian diperoleh angka Keiser-Meyer-Olkin (KMO) Measure of Sampling Adequacy (MSA) sebesar 0,622 >0,5 hal ini berarti bahwa analisis faktor dapat digunakan untuk menganalisis data yang diperoleh. Hasil uji Barlett's Test of Sphericity menunjukkan hasil yang signifikan sebesar 0,000<0,05.
Hal ini berati matrik korelasi yang signifikan dengan sejumlah variabel, karena nilai signifikan lebih kecil dari 0,05. Hasil output Statistical Program Social Science (SPSS) 16.0 for Windows (Anti-image Matrices), dapat diketahui faktor-faktor layak digunakan dalam analisis faktor terdapat kode "a" yang artinya tanda untuk Measure 
of Sampling Adequacy (MSA). Faktor yang layak digunakan dalam analisis adalah faktor yang memiliki nilai MSA $>0,5$. Apabila terdapat faktor yang memiliki MSA
$<0,05$, maka faktor tersebut dikeluarkan agar dapat dilakukan analisis faktor. Nilai MSA masing-masing faktor dilihat pada tabel

Tabel 2. Nilai Measure of Sampling Adequacy (MSA)

\begin{tabular}{lcc}
\hline \multicolumn{1}{c}{ Faktor } & Nilai MSA & Keputusan \\
\hline Budaya & $0,881>0,5$ & Dapat digunakan untuk analisis factor \\
Sosial & $0,602>0,5$ & Dapat digunakan untuk analisis factor \\
Pribadi & $0,581>0,5$ & Dapat digunakan untuk analisis factor \\
Psikologis & $0,569>0,5$ & Dapat digunakan untuk analisis factor \\
\hline
\end{tabular}

Berdasarkan tabel 2, maka dapat diketahui faktor-faktor yang digunakan dalam analisis factor yaitu faktor budaya, faktor sosial, faktor pribadi, dan faktor psikologis. Oleh karena itu, untuk menentukan banyaknya faktor yang mempengaruhi keputusan pembelian produk pada Distro Legend Store di Kecamatan Nusa Penida, dapat dijelaskan oleh nilai persentase dari masing-masing faktor.

Nilai total Variance Explained digunakan untuk mengetahui persentase dari empat faktor yang dianalisis. Hasil analisis faktor melalui SPSS 16.0 for Windows menunjukkan persentase dari masing-masing faktor dapat dilihat pada tabel

Tabel 3. Total Variance Explained

\begin{tabular}{|c|c|c|c|c|c|c|}
\hline \multirow[b]{2}{*}{ Component } & \multicolumn{3}{|c|}{ Initial Eigenvalues } & \multicolumn{3}{|c|}{ Extraction Sums of Squared Loadings } \\
\hline & Total & $\begin{array}{c}\% \text { of } \\
\text { Variance }\end{array}$ & Cumulative \% & Total & $\begin{array}{c}\% \text { of } \\
\text { Variance }\end{array}$ & Cumulative \% \\
\hline$\overline{P r i b a d i}$ & 2.476 & 61.901 & 61.901 & 2.476 & 61.901 & 61.901 \\
\hline Sosial & .736 & 18.388 & 80.289 & & & \\
\hline Psikologis & .601 & 15.023 & 95.312 & & & \\
\hline Budaya & .188 & 4.688 & 100.000 & & & \\
\hline
\end{tabular}

Berdasarkan tabel 3, dapat dilihat bahwa faktor Pribadi memiliki eigenvalue sebesar 2,476 dengan nilai variance sebesar $61,901 \%$, faktor Sosial memiliki eigenvalue sebesar 0,736 dengan nilai variance sebesar 18,388\%, faktor Psikologis memiliki eigenvalue sebesar 0,601 dengan nilai variance sebesar $15,023 \%$, faktor Budaya memiliki eigenvalue sebesar 0,188 dengan nilai variance sebesar $4,688 \%$. Jadi keempat faktor-faktor tersebut mempengaruhi keputusan pembelian produk pada distro Legend Store di Kecamatan Nusa Penida.
Tahap selanjutnya adalah menjelaskan faktor yang paling mempengaruhi keputusan pembelian produk pada Distro Legend Store di Kecamatan Nusa Penida, dapat dilakukan dengan ekstraksi faktor. Ekstraksi faktor dapat dijelaskan oleh total persentase masing-masing faktor utama. Faktor-faktor utama tersebut adalah faktor pribadi eigenvalue $>1$. Oleh karena itu, untuk mengetahui distribusi dimensi-dimensi yang belum dirotasi ke dalam faktor yang telah terbentuk, maka dapat dilihat Rotated Component
Matrix. 
Faktor yang menjelaskan keputusan pembelian produk pada Distro Legend
Store di Kecamatan Nusa Penida, dapat dilihat pada tabel 4.

Tabel 4. Faktor yang Menjelaskan Keputusan Pembelian Produk pada Distro Legend Store di Kecamatan Nusa Penida

\begin{tabular}{cccc}
\hline Faktor & Eigenvalues & $\begin{array}{c}\text { Variance } \\
\text { Explained (\%) }\end{array}$ & Loading Factor \\
\hline Pribadi & 2.476 & 61.901 & 0.923 \\
Sosial & 0.736 & 18.388 & 0.762 \\
Psikologis & 0.601 & 15.023 & 0.735 \\
Budaya & 0.188 & 4.688 & 0.710 \\
\hline
\end{tabular}

Berdasarkan tabel 4, dapat dijelaskan bahwa faktor yang memiliki eigenvalue $>1$ adalah faktor pribadi. Total nilai variance explained dari faktor pribadi mampu menjelaskan sebesar $61.901 \%$. Oleh karena itu, 61.901\% dari seluruh faktor yang ada, dapat dijelaskan oleh satu faktor yang terbentuk. Faktor pribadi memiliki variance explained $61.901 \%$, artinya bahwa faktor pribadi mampu menjelaskan keputusan pembelian produk pada Distro Legend Store di Kecamatan Nusa Penida sebesar $61.901 \%$.

Penentuan nama faktor yang telah terbentuk untuk masing-masing faktor bersifat subjektif, kadangkala variabel yang memiliki nilai faktor loading tertinggi digunakan untuk memberi nama faktor. Untuk melihat nilai faktor loading dapat dilihat pada tabel 5.

Tabel 5. Nilai Faktor Loading

Rotated Component Matrix

\begin{tabular}{lc}
\hline & \multicolumn{2}{c}{ Component } \\
\cline { 2 - 3 } & \multicolumn{2}{c}{1} \\
Pribadi & .923 \\
Sosial & .762 \\
Psikologis & .735 \\
Budaya & .710 \\
\hline
\end{tabular}

Berdasarkan tabel 5, faktor yang terbentuk dari faktor pribadi, faktor sosial, faktor psikologis, dan faktor budaya. Masing-masing kelompok faktor tersebut memiliki loading tertinggi di setiap komponen, yaitu faktor pribadi sebesar 0,923, faktor sosial sebesar 0,762, faktor psikologis sebesar 0,735 , dan faktor budaya sebesar 0,710.

Berdasarkan pengujian hipotesis penelitian, untuk menentukan dimensi atau
Faktor yang paling dominan mempengaruhi keputusan pembelian produk pada Distro Legend Store di Kecamatan Nusa Penida, digunakan parameter koefisien varimax mendekati +1 dan -1 .

Nilai yang mendekati +1 diawali oleh nilai 0,5 sedangkan nilai yang mendekati -1 diawali oleh $-0,5$. Secara lebih rinci hasil ringkasan rotasi dari matrik faktor memuat nilai varimax rotation, dapat dilihat pada tabel 
Tabel 6. Matriks Rotasi Hasil Analisis Faktor

Dimensi atau faktor keputusan pembelian produk pada Distro Legend Store di Kecamatan Nusa Of Variance (\%) Varimax Rotation Penida

\section{Pribadi}

Berdasarkan tabel 6, dapat diketahui bahwa faktor yang paling dominan yang mempengaruhi keputusan pembelian produk pada Distro Legend Store di Kecamatan Nusa Penida adalah faktor Pribadi dengan nilai varimax rotation 0,923 medekati +1 dengan variance sebesar $61,901 \%$. Artinya kejelasan dari dimensi atau faktor keputusan pembelian produk pada Distro Legend Store di Kecamatan Nusa Penida yang paling mendominasi sebesar $61,901 \%$.

\section{Pembahasan}

Berdasarkan hasil penelitian dapat diketahui bahwa faktor yang mempengaruhi keputusan pembelian produk pada Distro Legend Store di Kecamatan Nusa Penida adalah faktor budaya, sosial, pribadi, dan psikologis. Hal ini sesuai dengan teori yang dinyatakan oleh Kotler (2005) bahwa faktor yang mempengaruhi keputusan pembelian, yaitu faktor budaya, faktor sosial, faktor pribadi, dan faktor psikologis. Oleh karena itu, untuk menjelaskan faktor yang mempengaruhi keputusan pembelian produk pada Distro Legend Store di Kecamatan Nusa Penida, dapat dilihat dari faktor-fakor yang paling mendekati +1 atau mendekai -1. Dari hasil rotasi terhadap faktor matriks pada varimax rotation, maka faktor yang paling mendominasi yaitu faktor pribadi dengan nilai variance explained sebesar $61.901 \%$.

Faktor pribadi merupakan faktor yang paling dominan mempengaruhi keputusan pembelian produk pada Distro Legend Store di Kecamatan Nusa Penida dibandingkan dengan faktor-faktor lain yang mempengaruhinya. Faktor ini paling dominan karena karakteristik masyarakat khususnya masyarakat di Kecamatan Nusa Penida Kabupaten Kulngkung mayoritas bekerja di sektor pertanian, nelayan, dan pegawai di bidang pariwisata. oleh karena itu, masyarakat di Kecamatan Nusa Penida perlu berpakaian atau berbusana untuk kegiatan sehari-hari.

Selain harga terjangkau, produk yang ditawarkan oleh Distro Legend Store mempunyai kualitas dan desain yang sangat bagus. Ketika ada produk baru dari Distro Legend Store, pemilik atau pegawai langsung memberikan informasi sedetail mungkin lewat sosial media sepert: instagram, facebook, dan twitter. Kepribadian seseorang jelas mempengruhi tingkah laku pembelinya. Faktor pribadi mengacu pada karakteristik psikologis unik yang menyebabkan respon relatif konsisten dan bertahan lama terhadap lingkungan dirinya sendiri. Kepribadian biasanya diuraikan dalam arti sifat-sifat seperti rasa percaya diri, dominasi, kemudahan bergaul, otonomi, mempertahankan diri, kemampuan menyesuaikan diri dan keagresifan. Kepribadian bermanfaat untuk pemilihan produk atau merek tertentu.

Dalam penelitian ini, faktor pribadi sangatlah penting sebagai faktor penentu seseorang untuk melakukan sebuah pembelian. Hal ini sesuai dengan teori Kotler (2005) yang menyatakan bahwa salah satu faktor yang mempengaruhi keputusan pembelian adalah faktor pribadi. Hasil penelitian ini sejalan dengan hasil penelitian yang dilakukan oleh Murdoyo (2014) faktor pribadi merupakan karakteristik pribadi sesorang yang berbeda dengan orang lain yang menyebabkan tanggapan yang relatif konsisten dan bertahan lama terhadap lingkungan. Faktor pribadi terdiri dari usia dan tahap siklus hidup, pekerjaan, keadaan ekonomi, gaya hidup, dan kepribadian sangat penting bagi perilaku keputusan pembelian.

Sebagai perbandingan terhadap penelitian terdahulu yang telah dilakukan, 
Gifary (2017) telah melakukan penelitian terhadap faktor-faktor yang mempengaruhi keputusan konsumen dalam pembelian minuman isotonik dimana studi kasus yang diangkat adalah pada miniman Mizone di Bandar Lampung. Terdapat persamaan menggunakan faktor-faktor yang mempengaruhi keputusan pembelian, meliputi faktor buday, sosial, pribadi dan psikologis. Sedangkan perbedaanya terlihat pada hasil faktor yang paling dominan mempengaruhi keputusan pembelian. Penelitian Gifary (2017) mempunyai faktor dominan yang terletak pada faktor budaya, sedangkan penelitian ini faktor dominannya adalah faktor pribadi dengan kontribusi sebesar 61,901\%. Hal kebaruan dari penelitian ini terhadap penelitian sebelumnya adalah bahwa faktor pribadi yang sebagai dominan dalam penentu keputusan pembelian bisa ditentukan berdasarkan varimex rotation.

\section{SIMPULAN DAN SARAN Simpulan}

Berdasarkan hasil penelitian dan pembahasan pada bagian sebelumnya, maka dapat diambil simpulan sebagai berikut. Pertama, ada empat faktor yang mempengaruhi keputusan pembelian produk pada Distro Legend Store di Kecamatan Nusa Penida, yaitu faktor pribadi yang memiliki eiginvelue sebesar 2,476 dengan nilai variance sebesar $61,901 \%$, faktor sosial yang memiliki eiginvelue sebesar 0,736 dengan nilai variance sebesar 18,388\%, faktor psikologis yang memiliki eiginvelue sebesar 0,601 dengan nilai variance sebesar $15,023 \%$, dan faktor budaya yang memiliki eiginvelue sebesar 0,188 dengan nilai variance sebesar $4,688 \%$. Kedua, faktor yang paling dominan mempengaruhi keputusan pembelian produk pada Distro Legend Store di Kecamatan Nusa Penida adalah faktor pribadi dengan nilai varimax rotation sebesar $61.901 \%$.

\section{Saran}

Berdasarkan simpulan di atas, maka saran yang dapat diajukan sebagai berikut. Pertama, bagi Distro Legend Store, faktor pribadi menjadi faktor utama yang perlu diperhatikan dalam penjualan produk- produk dibandingkan dengan faktor lainnya. Faktor pribadi yang meliputi usia dan tahap siklus hidup, pekerjaan, keadaan ekonomi, gaya hidup, dan kepribadian mencapai $61,901 \%$ dalam menentukan keinginan konsumen untuk membeli produk di distro Legend Store yang berdasarkan hasil penelitian yang didapat. Jika faktor pribadi ini diperhatikan dengan baik oleh Distro Legend Store, maka penjualan secara otomatis akan bisa meningkat secara signifikan. Selain itu, hal lain yang bisa membantu meningkatkan penjualan adalah pelayan-pelayan di Distro Legend Store harus ramah kepada konsumen dan barang-barang yang dijual sesuai dengan kebutuhan konsumen. Kedua, bagi peneliti lain, penelitian ini bisa dikembangkan menjadi lebih dari empat faktor yang sudah digunakan dalam penelitian ini. Penambahan dua faktor seperti faktor ekonomi dan faktor teknologi bisa menjadi sebuah pengembangan penelitian ini yang sudah menggunakan empat faktor yaitu faktor budaya, faktor sosial, faktor pribadi, dan faktor psikologis.

\section{DAFTAR PUSTAKA}

Gifary, Muhammad. 2017. "Faktor-Faktor Yang Mempengaruhi Keputusan Konsumen Dalam Pemebelian Minuman Isotonik (Studi Kasus Pada Mizone Di Bandar Lampung)". http://digilib.unila.ac.id/25948/20/SKRI PSI TANPA BAB PEMBAHASAN.pdf. Kotler, Philip. 2002. Manajemen Pemasaran. Edisi Milenium. Jakarta: PT. Prenhalindo.

_. 2005. Manajemen Pemasaran. Edisi Kesebelas. Jakarta: PT. Indeks Kelompok Gramedia. dan Gary Amstrong. 2001. PrinsipPrinsip Pemasaran. Edisi Kedelapan. Jakarta: Erlangga.

- 2008. Prinsip-Prinsip Pemasaran. Edisi Keduabelas. Jakarta: Erlangga.

Munandar, A.S. 2001. Psikologi Industri Dan Organisasi. Depok: Universitas Indonesia (UI Press).

Murdoyo, Totok. 2014. "Analisis FaktorFaktor Yang Mempengaruhi Konsumen Dalam Pengambilan Keputusan Pembelian Produk Sepatu Futsal Merk Adidas Pada Pelanggan 
Lapangan Futsal Gor Surya Di Boyolali”. Naskah Publikasi: Februari 2014. hlm 1-59.

Riduwan. 2008. Cara Menggunakan Analisis Jalur. Bandung: Alfabeta. Schifman, Leon G. dan Leslie L. Kanuk.

2000. Consumer Behavior. Fifth Edition. New Jersey: Prentice-Hall Inc.

- 2004. Perilaku Konsumen. Edisi Ketujuh. Jakarta: Prentice Hall.

Sugiyono. 2007. Metode Penelitian Kuantitatif, Kualitatif, dan R\&D. Bndung: Alfabeta.

- 2008. Metode Penelitian Bisnis (Pendekatan Kualitatif, Kuantitatif, dan $R \& D)$. Bandung: Alfabeta.

- 2013. Metode Penelitian Kuantitatif, Kualitatif, dan R\&D. Bandung: Alfabeta.

Sujarweni, V. Wiratna. 2015. Metodelogi Penelitian Bisnis dan Ekonomi. Yogyakarta: Pustaka Baru Press.

Swasta, Basu dan Tani Hani Handoko. 2000. Manajemen Pemasaran: Analisis dan Perilaku Konsumen. Yogyakarta: BPFE.

Umar, Husein. 2003. Metode Riset Bisnis Dilengkapi Contoh Proposal dan Hasil Riset Bidang Manajemen dan Akuntansi. Jakarta: PT. Gramedia Pustaka Utama. 